\title{
PROFILING OF METABOLIC BIOMARKERS IN THE SERUM OF PROSTATE CANCER PATIENTS
}

\author{
F. ALI $I^{1}$ S. AKRAM ${ }^{1}$, S. NIAZ $Z^{1,2}$, N. WAJID ${ }^{1}$ \\ ${ }^{1}$ Institute of Molecular Biology and Biotechnology (IMBB) \& Centre for Research In Molecular \\ Medicine (CRIMM), The University of Lahore, Raiwind Road Lahore, Pakistan; \\ ${ }^{2}$ Social Security Hospital Multan Chungi, Multan Road, Lahore; \\ e-mail: Fatima.ali@imbb.uol.edu.pk; fatemei.ali@gmail.com
}

Received: 26 July 2019; Accepted: 29 November 2019

Prostate cancer (PCa) is the major cause of the death of men population globally. Multiple factors are involved in the initiation and progression of PCa. This study aimed to evaluate different metabolic parameters in the serum of PCa patients. Males of 50 years and above age with the recent diagnosis of PCa (digital rectal examination, and elevated serum prostate-specific antigen (PSA) level) were included in the study. Glucose and serum electrolytes level, lactate dehydrogenase activity, parameters of lipid metabolism and liver and kidney functioning were measured on a fully automated analyzer using standard reagent kits. Oxidative stress was evaluated by measuring MDA, CAT, GSH, and SOD in serum. Detection of C-reactive protein (CRP), insulin-like growth factor (IGF-1) and vascular endothelial growth factor (VEGF) was performed by immunoassay. It was shown that serum glucose and HDL levels were lower while total cholesterol, LDL and triglyceride levels were significantly higher in PCa group than in the control group. PCa patients had an elevated level of liver and kidney functional markers. Comparison of the oxidative stress markers in patient and control groups showed significant difference. It was detected that serum levels of CRP, IGF-1 and VEGF were significantly higher in PCa group, compared the control to group $(P<0.05)$. Low level of glucose and dyslipidemia indices in prostate cancer patients indicated metabolic changes and demonstrated the importance of multiple parameters analysis (free PSA, dyslipidemia, VEGF, IGF-1, CRP, and oxidative stress markers) for early PCa diagnostics.

Ke y wo rd s: prostate cancer, oxidative stress, insulin-like growth factor, vascular endothelial growth factor, c-reactive protein.

$\mathrm{P}$ rostate cancer $(\mathrm{PCa})$ is the second most common malignancy in men above 55 years of age and the fifth leading cause of mortality in men worldwide $[1,2]$. Certain modifiable and nonmodifiable risk factors contribute to the progression of PCa [3]. Non-modifiable risk factors include age, ethnicity, and family history [4], whereas modifiable risk factors include obesity, smoking, hypertension, diabetes mellitus (DM) and dyslipidemia [5]. Aging, inflammation, and oxidative stress-induced DNA damage also play important role in the progression of PCa [6-8].

PCa is a slow-growing malignant tumor which remains asymptomatic in the majority of patients hence detected in later stages by biopsy. Current- ly, the digital rectal examination (DRE) and a serum prostate-specific antigen (PSA) tests are common diagnostic tools for PCa [9]. There are many treatment options for PCa depending on a patient's medical history, diagnosis, age, and current state of health. Epidemiologic studies suggest that the use of lycopene, $\beta$-carotene, vitamins $\mathrm{C}$, $\mathrm{E}$, and selenium supplement may reduce the risk of advanced-stage disease [10], whereas aspirin, ibuprofen, and higher vegetable intake may decrease the risk of non-advanced-stage disease and low-grade prostate cancer [11]. Treatments for PCa may include radical prostatectomy, radiotherapy alone or in combination with other therapies such as adjuvant treatments by hormonal agent's administration which suppresses the

(C) 2020 Ali F. et al. This is an open-access article distributed under the terms of the Creative Commons Attribution License, which permits unrestricted use, distribution, and reproduction in any medium, provided the original author and source are credited. 
endogenous testosterone production [12]. Hormone therapy known as androgen deprivation therapy (ADT) is commonly used to treat advanced prostate cancer however, it is associated with numerous side effects that can influence the quality of life. Metabolic syndrome, sexual dysfunction, osteoporosis, osteoarthritis, gynecomastia, obesity, insulin resistance, diabetes, dyslipidemia, hypertension, cardiovascular disease and depression are well-described complications of androgen deprivation therapy [13-16].

Other biochemical abnormalities may also present in patients that disturb gonadal steroid hormone, insulin and insulin-like growth factor-I (IGF-I) levels [17]. Literature shows that alteration in IGF-I level may be concordant with a high risk of PCa development as IGF-I is a potent mitogenic factor involved in cell proliferation, differentiation, and apoptosis, hence its high level is susceptible for the transformation of normal cells into malignant cells [19].

The rate of PCa incidence is increasing worldwide $[1,19]$. The principle reasons include variation in screening methods and treatment in Western and Asian countries [20, 21]. The most suitable way to deal with this situation is individualized screening in light of epidemiological and financial status of every nation. Keeping in view the above information, It is hypothesized that certain metabolic parameters like dyslipidemia, oxidative stress are significant for early-stage diagnosis of prostate cancer for early treatment.

\section{Materials and Methods}

Subjects and study design. This case-control study included 120 subjects; out of which 60 subjects were with normal digital rectal examination and PSA levels (0-4 ng/ml) (control group), and 60 subjects were with abnormal digital rectal examination, and elevated PSA levels (>4.0) (PCa group), visiting the outpatient clinic at Department of Urology at Sharif Medical City Hospital Lahore, Pakistan from September 2017 to October 2018.

Inclusion and Exclusion Criteria. This study included males of age 50 years and above with newly confirmed diagnoses of $\mathrm{PCa}$, who were not taking androgen deprivation therapy, and any cancer-related medicine. Age-matched males (control subjects) were included in the study.

Subjects who had a history of any of the following were excluded from the study: prostatitis, benign prostatic hyperplasia, other prostate-related diseases with any other urinary complaints, or who underwent any urethral manipulation, or mechanical disturbance of gland before test, with history of diabetes, as well as patients who did exercise or who ejaculated for a day or two before test. The reason to exclude other prostate-related disease i.e. prostatitis which is due to inflammation usually caused by bacteria affect the inflammatory markers results. Benign prostatic hyperplasia, which is other prostate-related disease, affects the testosterone level and all these prostate diseases affect the PSA level so it will lead to misinterpretation of results. Subjects were excluded from the study if they had previously been prescribed medications for PCa and androgen deprivation therapy.

Ethical Consideration. Official approval for the study was obtained from the institutional review board and ethics committee of the Department of Urology at Sharif Medical City Hospital Lahore, Pakistan. The researchers explained the purpose and objectives of the study to all participants included in the analysis. The inclusion in the study was optional and confidential.

Baseline Data Collection. Patient background and medical history data were collected via questionnaire. Questionnaire for the baseline data collection was prepared based on demographic and socioeconomic characteristics, ethnicity, marital status, educational level, employment status, perception, awareness and related knowledge for the disease. The mean rate of enrollment refusal was $0 \%$.

Collection of Blood and Isolation of Serum. Blood samples were collected before any prostatic manipulation, followed by digital rectal examination. Venous blood was drawn from the cubital vein from all subjects and instantly transferred from hospital to CRIMM laboratory in an icebox. Blood samples were centrifuged at $2000 \mathrm{~g}$ for $10 \mathrm{~min}$ at $4{ }^{\circ} \mathrm{C}$. Serum was aspirated, aliquoted, and stored at $-20^{\circ} \mathrm{C}$ for future analysis.

Biochemical parameters. Samples were used to determine the following parameters by commercially available kits.

Determination of TPSA and PPSA. The tPSA level was determined using commercially available total PSA ELISA kit (MP Biomedicals Diagnostics, USA). The fPSA was determined by using commercially available fPSA ELISA kit (MP Biomedicals Diagnostics, USA).

Blood chemistry. The concentration of fasting blood glucose (FBG), lactate dehydrogenase (LDH), serum calcium, and serum phosphorus was deter- 
mined by using commercially available kits (Randox laboratories Ltd., UK). Reference values are shown in Table 2.

Determination of lipid profile. Serum levels of total cholesterol (TC), triglycerides (TG), and highdensity lipoprotein (HDL) were measured spectrophotometrically using commercial assay kits (Randox laboratories Ltd., United Kingdom). LDL was calculated by using Friedewald formula. Reference values shown in Table 2.

Determination of liver profile. Alanine aminotransferase (ALT), aspartate aminotransferase (AST), and Alkaline Phosphatase (ALP) were assessed using commercial kits (Randox laboratories Ltd, United Kingdom). Reference values are shown in Table 2.

Evaluation of renal functions. Urea was analyzed by using commercially available kit (AMP Diagnostics). Blood urea nitrogen (BUN) was calculated by the formula (Blood urea $=2.14 * \mathrm{BUN}$ ). Blood urea nitrogen values were calculated by dividing the blood urea level by 2.14. Creatinine was estimated by using Roche Diagnostics kit on Hitachi-911 analyzer. Reference values are shown in Table 2.

Estimation of oxidative stress. Oxidative stress was measured by analyzing the level of malondialdehyde (MDA), catalase (CAT), glutathione (GSH), superoxide dismutase (SOD) in serum. These markers were determined by manual method as previously described by us [22].

Analysis of Growth Factors and Inflammation Maker by ELISA. The indirect ELISA was performed by plating $20 \mu \mathrm{g}$ serum sample of both groups in volume of $100 \mu \mathrm{l} /$ well, overnight at $4{ }^{\circ} \mathrm{C}$. The next day the plates were washed once with $100 \mu 1 /$ well of $1 x$ PBST (1x PBS with $0.05 \%$ Tween 20, pH 7.2) wash buffer. Then non-specific sites were blocked with 5\% BSA for $2 \mathrm{~h}$ at room temperature, subsequently the plates were washed 3 times at 10 min interval with $1 \mathrm{x}$ PBST, $\mathrm{pH}$ 7.2. The wells were then incubated with primary antibodies i.e. mouse anti-vascular endothelial growth factor (VEGF) (1:200), rabbit anti-insulin-like growth factor (IGF-I) (1:200), mouse anti-C-Reactive Protein (CRP) (1:200), and mouse anti- $\beta$-actin (1:200) (Santa Cruz Biotechnology, USA) for 1 hour. The wells were then subjected to 3 times wash with $1 \mathrm{x}$ PBST at 10 min interval with 1x PBST, pH 7.2 and incubated with HRP-conjugated anti-mouse (1:1000) and HRP-conjugated anti-rabbit secondary (1:1000) antibodies (SantaCruz Biotechnology, USA) for $1 \mathrm{~h}$. After washing, equal volume of chromogenic solution 3,3',5,5'-tetramethylbenzidine (TMB) (Invitrogen Inc., USA) was added then $0.1 \mathrm{mM}$ hydrochloric acid $(\mathrm{HCl})$ was added to stop reaction and plate was read at $650 \mathrm{~nm}$ in BioTek plate reader. Each of the test samples was tested in triplicate and average absorbance values were statistically analyzed.

Dot blot analysis for growth factors and inflammation maker. Serum samples $(2 \mu \mathrm{g} / \mathrm{ml})$ concentration of both groups were added at $10 \mu \mathrm{l} / \mathrm{dot}$ to nitrocellulose membranes (Bio Rad). The membranes were air-dried and blocked in 5\% BSA/PBS, pH 7.2, for $30 \mathrm{~min}$. The membranes were then washed 3 times at 10 min interval with $1 x$ PBS, $\mathrm{pH}$ 7.2. The membranes were then incubated with the VEGF (1:200), IGF-I (1:200), CRP (1:200), and $\beta$-actin (1:200) (Santa Cruz Biotechnology, USA) for $1 \mathrm{~h}$ with rocking. The membranes were subjected to 3 times wash with $1 \mathrm{x}$ PBS for $30 \mathrm{~min}$ at $10 \mathrm{~min}$ interval with $1 \mathrm{x}$ PBS, pH 7.2 and incubated with HRPconjugated anti-mouse (1:1000) and HRP-conjugated anti-rabbit secondary (1:1000) antibodies (Santa Cruz Biotechnology, USA) for $1 \mathrm{~h}$, and developed with chromogen substrate 3,3'-diaminobenzidine tetrahydro-chloride (DAB) plus $\mathrm{H}_{2} \mathrm{O}_{2}$ solution in the dark. The integrated density of respective images was quantified by using Image J analysis software.

Statistical analysis. Statistical analysis was performed using GraphPad Prism version 5.00 for Windows (GraphPad Software, San Diego, CA, USA). Unpaired Student's t-test was performed for comparison between two groups' data. Data were presented as Mean \pm standard deviation (SD). $P<0.05$ was considered statistically significant.

\section{Results and Discussion}

Demographic Characteristics of Subjects. The characteristics of the study population were illustrated in Table 1. Control group had mean age of $54.0 \pm 10.3$ years, whereas PCa group had mean age $55.0 \pm 13.4$ years. PSA level was high in $\mathrm{PCa}$ group compared with control group. tPSA and tPSA/ fPSA levels were significantly higher in PCa group $(P<0.001)$ compared with Non-PCa group. Results of basic demographic characteristics are shown in Table 1.

Blood chemistry analysis. Parameters of blood chemistry of control and PCa groups are summarized in Table 2. There was significantly higher lactate dehydrogenase level in PCa group whereas 
Table 1. Demographic characteristics of PCa patients

\begin{tabular}{l|c|c}
\hline \multicolumn{1}{c|}{ Characteristics } & $\begin{array}{c}\text { Normal group } \\
\text { (60 subjects) }\end{array}$ & $\begin{array}{c}\text { PCa group } \\
\text { (60 subjects) }\end{array}$ \\
\hline $\begin{array}{l}\text { Age, years } \\
\text { Total PSA } \\
\text { (tPSA), ng/ml }\end{array}$ & $54.0 \pm 0.3$ & $55.0 \pm 13.4$ \\
$\begin{array}{l}\text { Free PSA } \\
\text { (fPSA), ng/ml }\end{array}$ & $1.08 \pm 0.98$ & $71.94 \pm 1.40$ \\
fPSA/tPSA ratio & $33.00 \pm 0.09$ & $15.0 \pm 15.4$ \\
\hline
\end{tabular}

All values are mean $\pm \mathrm{SD}$. PCa patients versus control, for all analyses, $P<0.05$ was considered statistically significant and designated as $P<0.001$

calcium and phosphorous levels were not changed significantly.

Alterations in levels of all the lipid constituents among all groups are presented in Table 2. PCa group showed significant increase in TC, TG, and LDL levels compared to that of control group. Whereas, PCa group showed significantly lower level of HDL. Also, PCa patients had high value of
TC/HDL and LDL/HDL ratios compared to the control group.

PCa group had significantly higher level of urea, creatinine, and blood urea nitrogen as compared to control group. The levels of liver functionrelated markers ALT, AST, and ALP were also found to be elevated in PCa group compared to control group (Table 2).

Effect of PCa on oxidative stress markers. Oxidative stress in PCa group was measured by evaluating the levels of GSH, SOD, CAT and MDA. It was observed that SOD activity $(0.16 \pm 0.07 \mathrm{~nm})$, and GSH level $(0.07 \pm 0.03 \mathrm{~nm})$ were significantly low in PCa group compared to control group for SOD $(0.44 \pm 0.15 \mathrm{~nm})$ and GSH $(0.16 \pm 0.04 \mathrm{~nm})$, (Fig. 1 , $A$ and $B)$. Increased MDA level $(0.61 \pm 0.18 \mathrm{~nm})$ and CAT activity $(1.52 \pm 0.29 \mathrm{~nm})$ was observed in PCa group compared to control group for MDA $(0.34 \pm 0.08 \mathrm{~nm})$ and CAT $(0.88 \pm 0.19 \mathrm{~nm})$, (Fig. 1 , $C$ and $D$ ).

Release of growth factors and inflammation maker in serum. To determine the levels of IGFI, VEGF, and CRP in the serum, ELISA was performed on study samples. As shown in Fig. 2, A-C,

Ta ble 2. Blood chemistry analysis of PCa patients

\begin{tabular}{l|c|c|c|c|c}
\hline \multicolumn{1}{c|}{ Parameters } & $\begin{array}{c}\text { Normal group } \\
\text { (60 subjects) }\end{array}$ & $\begin{array}{c}\text { PCa group } \\
\text { (60 subjects) }\end{array}$ & $P$-Value & Siginificance & Reference range \\
\hline FBG, mg/dl & $97.08 \pm 9.30$ & $69.92 \pm 13.00$ & $<0.0001$ & $* * *$ & 70 to $99 \mathrm{mg} / \mathrm{dl}$ \\
LDH, U/l & $205.00 \pm 0.11$ & $891.00 \pm 0.29$ & $<0.0001$ & $* * *$ & $140-280 \mathrm{U} / \mathrm{l}$ \\
Calcium, mg/dl & $8.62 \pm 0.60$ & $9.6 \pm 0.1$ & 0.035 & $*$ & $8.5-10.2 \mathrm{mg} / \mathrm{dl}$ \\
Phosphorous, mg/dl & $2.54 \pm 0.20$ & $4.1 \pm 1.2$ & 0.021 & $*$ & 2.4 to $4.1 \mathrm{mg} / \mathrm{dl}$ \\
Cholesterol, mg/dl & $177.2 \pm 12.0$ & $447.3 \pm 164.8$ & $<0.0001$ & $* * *$ & $<200 \mathrm{mg} / \mathrm{dl}$ \\
Triglycerides, mg/dl & $80.9 \pm 30.6$ & $200.1 \pm 45.3$ & $<0.0001$ & $* * *$ & $150 \mathrm{mg} / \mathrm{dl}$ \\
LDL, mg/dl & $139.0 \pm 12.9$ & $247.7 \pm 24.2$ & $<0.0001$ & $* * *$ & $<40 \mathrm{mg} / \mathrm{dl}$ \\
HDL, mg/dl & $40.3 \pm 5.2$ & $25.0 \pm 2.9$ & $<0.0001$ & $* * *$ & $100-129 \mathrm{mg} / \mathrm{dl}$ \\
TC/HDL & $4.14 \pm 5.20$ & $16.69 \pm 1.12$ & $<0.0001$ & $* * *$ & $<5.0$ \\
LDL/HDL & $3.5 \pm 0.1$ & $9.92 \pm 0.32$ & $<0.0001$ & $* * *$ & $<5.0$ \\
Urea, mg/dl & $17.0 \pm 2.6$ & $56.0 \pm 13.0$ & $<0.0001$ & $* * *$ & $15-45 \mathrm{mg} / \mathrm{dl}$ \\
BUN, mg/dl & $7.9 \pm 1.2$ & $26.1 \pm 6.0$ & $<0.0001$ & $* * *$ & $8-21 \mathrm{mg} / \mathrm{dl}$ \\
Creatinine, mg/dl & $0.78 \pm 0.15$ & $1.22 \pm 0.16$ & $<0.0001$ & $* * *$ & $0.8-1.4 \mathrm{mg} / \mathrm{dl}$ \\
ALT, U/l & $21.6 \pm 1.5$ & $74.0 \pm 17.0$ & 0.0061 & $* *$ & up to $40 \mathrm{U} / \mathrm{l}$ \\
AST, U/l & $17.6 \pm 5.6$ & $82.0 \pm 15.6$ & 0.0026 & $* *$ & up to 37 U/l \\
ALP, U/l & $100.7 \pm 19.0$ & $243.3 \pm 30.0$ & 0.0008 & $* * *$ & $44-147 \mathrm{U} / \mathrm{l}$ \\
\hline
\end{tabular}

All values are mean \pm SD. PCa patients versus control, for all analyses, $P<0.05$ was considered statistically significant and designated as $* P<0.05,{ }^{* *} P<0.01,{ }^{* * *} P<0.001$ 
$A$

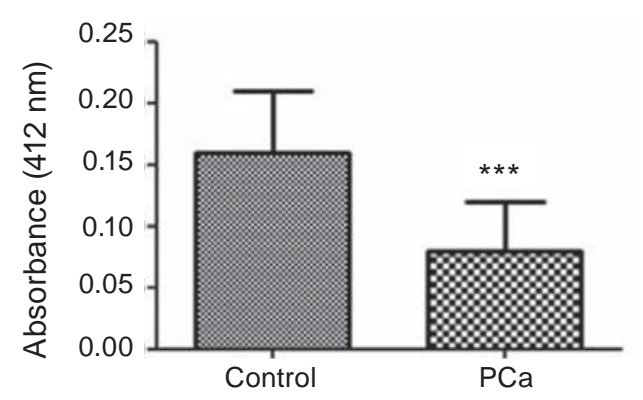

C

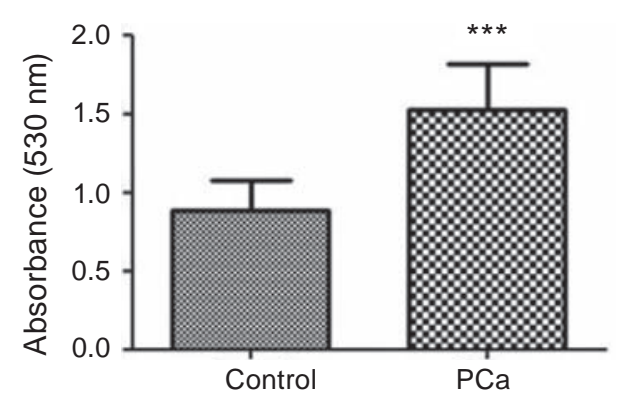

B

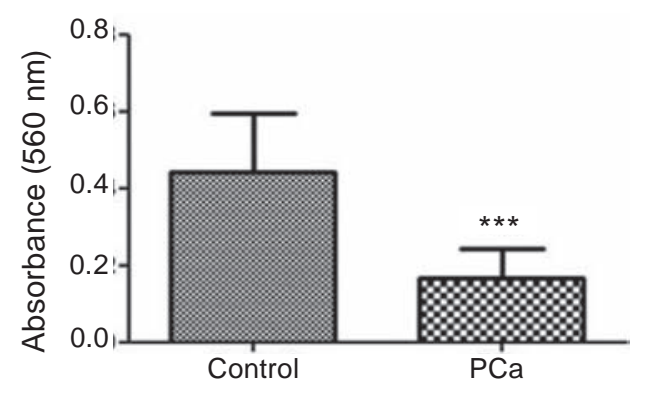

D

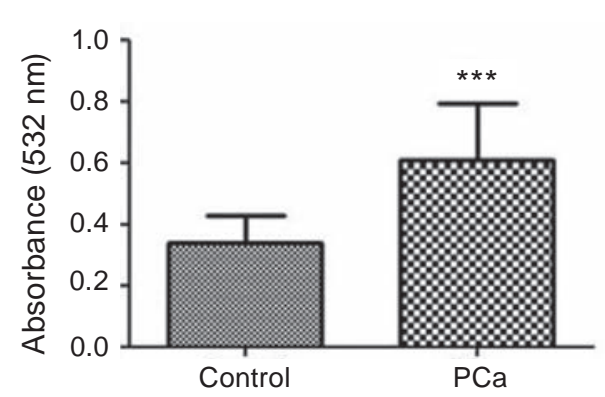

Fig. 1. Assessment of oxidative stress markers in PCa and control groups. A: Reduced glutathione (GSH). B: Superoxide dismutase (SOD). C: Catalase (CAT). D: Malondialdehyde (MDA). All values were expressed as mean $\pm S D$. $P C a$ versus control, for all analyses, $P<0.05$ was considered statistically significant and designated as ${ }^{* * *} P<0.001$ in the figure

the serum levels of IGF-I and VEGF in the PCa group were $(0.39 \pm 0.08 \mathrm{~nm})$ and $(0.83 \pm 0.19 \mathrm{~nm})$, respectively; these levels were higher than those in the control group $(0.23 \pm 0.07 \mathrm{~nm})$ for IGF-I and $(0.38 \pm 0.05 \mathrm{~nm})$ for VEGF $(P<0.05)$. The serum level of CRP in the PCa group was $(1.26 \pm 0.06 \mathrm{~nm})$ and in non-PCa individuals - $(0.91 \pm 0.30 \mathrm{~nm})$.

The protein expression of growth factors (VEGF and IGF-I) and inflammation marker (CRP) shown in Fig. 2 were analyzed through dot blot. Significant increase in the expression of VEGF $(173 \pm 2.0)$, IGF-I $(191.3 \pm 1.5)$ and CRP $(237.7 \pm 6.6)$ was observed in PCa patients compared to control group for VEGF (102.3 \pm 1.5$)$, IGF-I (103.7 \pm 2.5$)$, and CRP (73.3 \pm 1.5$)$, respectively (Fig. $2, E-G)$. $\beta$-actin was used as an internal control.

$\mathrm{PCa}$ is a common urologic disorder, affecting the quality of life of aged men. There are numerous epidemiological studies on the relationships between the risk factors and development of PCa [23]. But few studies have focused on the risk factor in local people. Thus, the present study was undertaken to assess metabolic and paracrine changes among men having PCa in the local population.
The results are consistent with previous studies, in which prostate cancer patients had elevated phosphate and calcium [24]. Another meta-analysis based study reported high serum lactate dehydrogenase levels in prostate cancer patients. Lactate dehydrogenase is a key energy-producing enzyme and potential predictive marker to guide individual therapy decisions in solid tumors [25]. The results of the present study are similar to those previously reported studies.

Previous studies have indicated that the life style of $\mathrm{PCa}$ patients plays significant role in the development of the disease [26]. High-fat diet consumption leads to accumulation of cholesterol and triglycerides in adipose tissue [27]. Studies suggest that hypercholesterolemia and dyslipidemia are among the major causes in the development of obesity and contribute well in the progression of PCa [28]. Dyslipidemia is described as decreased serum HDL, increased LDL and triglycerides. Study results show an increased level of cholesterol, LDL, triglycerides and decreased HDL level indicate dyslipidemia in PCa patients. 
A

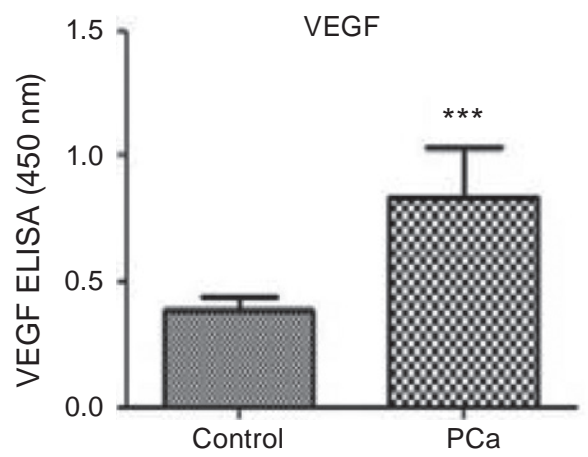

C

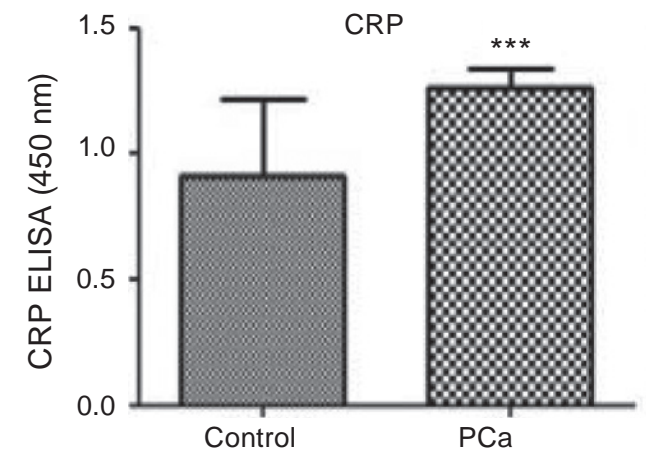

E

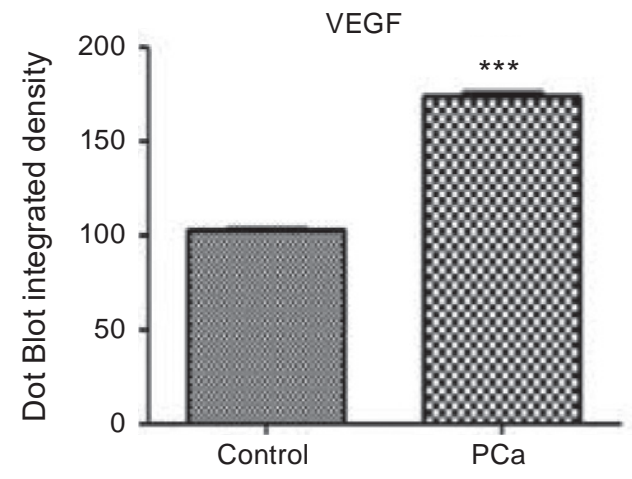

G

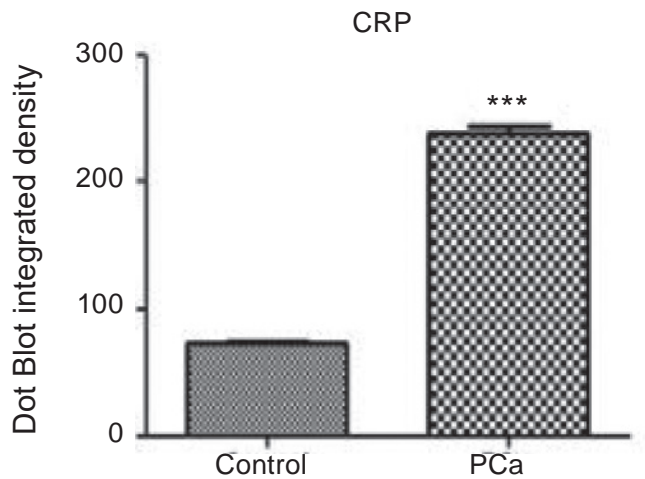

B

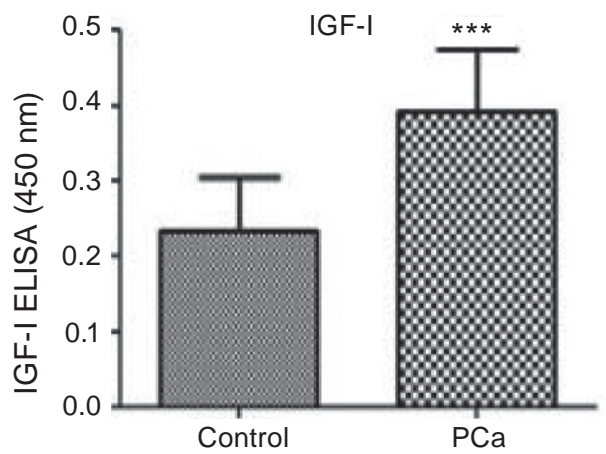

D

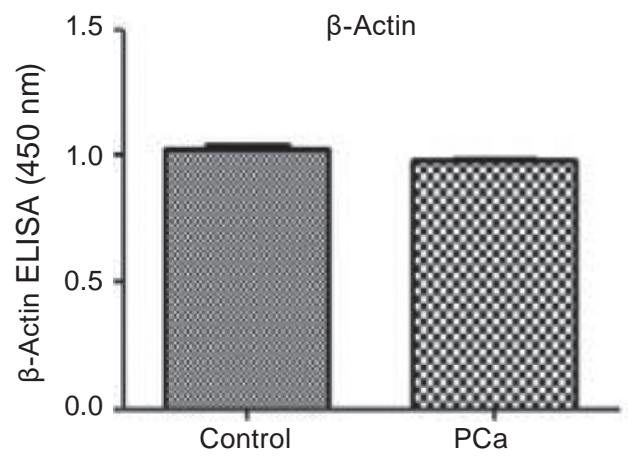

$\boldsymbol{F}$

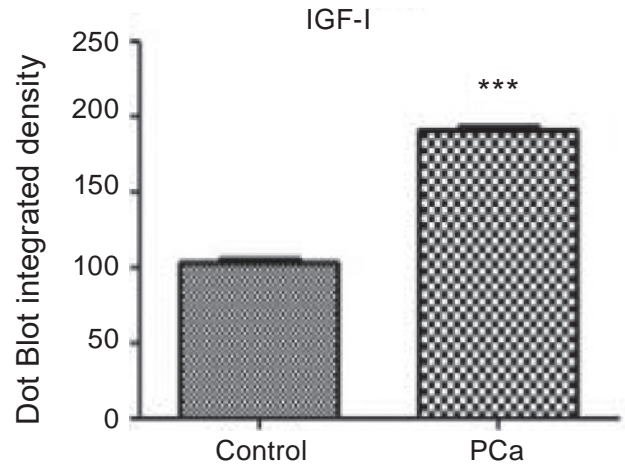

H

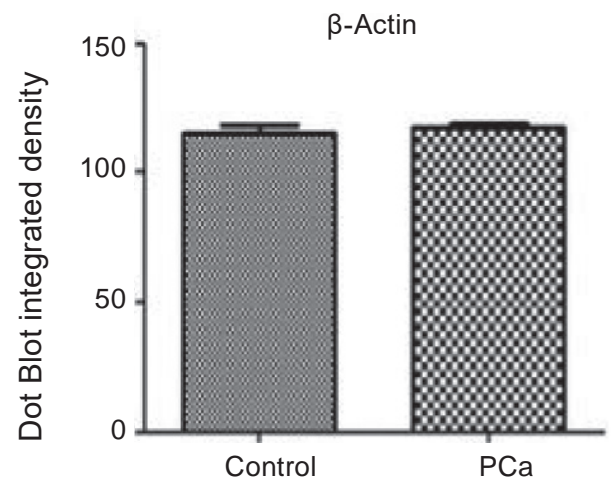

Fig. 2. Evaluation of growth factors and inflammation maker in PCa and control groups. A, E: Vascular endothelial growth factor (VEGF). B, F: Insulin-like growth factor-1 (IGF-I). C, G: C-reactive protein (CRP). All values were expressed as mean $\pm S D$. PCa versus control, for all analyses, $P<0.05$ was considered statistically significant and designated as $* * * P<0.001$ in the figure 
Epidemiological and pre-clinical studies suggest that elevated levels of cholesterol could play a role in PCa progression. Tumors in hypercholesterolemic environment exhibit lower levels of apoptosis, increased activation of Akt kinase, related to aggressive PCa and increased vascularization [29-31]. Angiogenesis is important for tumor growth and can be measured by the level of VEGF, which plays an important role in the progression of PCa [32]. Our results show elevated VEGF in the serum of prostate patients which signifies the importance of VEGF estimation in diagnosis of the disease.

IGF-I is a peptide growth factor and a strong mitogen for the growth of androgen-dependent and androgen-independent PCa [33, 34]. Studies suggest that IGF-I plays an important role in initiation and progression of PCa. In a normal individual the normal level of prostate serum antigen controls semen life [35]. However, the increase in prostate serum antigen level promotes the metastasis of cancer. Previous studies showed that PSA digest the insulin-like growth factor binding protein 3 (IGFBP-3) hence releasing the IGF-I [36]. This free IGF has the potential to show its insulin-like properties leading to enhanced consumption of glucose [37]. Our results showed that the IGF-I level was significantly higher in the PCa group.

Oxidative stress is an imbalance between oxidative and anti-oxidative systems of cells and tissues that results in overproduction of reactive oxygen species (ROS) [6]. Oxidative stress and chronic inflammation are known to be associated with the development of metabolic diseases and disturbed organ functions [7, 8]. In the current analysis, we hypothesized that oxidative stress may results in renal and hepatic dysfunction in PCa patients therefore, we determine the functioning of kidney and liver. Our results showed disturbed renal (urea, blood urea nitrogen, creatinine) and hepatic function (ALT, AST and ALP) in PCa patients, which suggests that it may be due to oxidative stress that triggers hepatic and renal functional impairment. Oxidative stress status among the PCa patients was evaluated by measuring lipid peroxidation end product MDA [38] and antioxidant GSH, SOD and catalase status [39]. We observed increased MDA while reduced GSH, SOD and CAT levels in PCa patients. Studies suggest that inflammation is another factor that is associated with a PCa development [6]. Inflammation can lead to a dramatic increase in ROS production, which further damaging tissues. CRP is a marker of systemic in- flammation. In our study, the serum CRP levels were found to be higher compared to the normal group [40].

In conclusion, the present study demonstrates the importance of multiple parameters (free PSA, dyslipidemia, VEGF, IGF-1, CRP, and oxidative stress) for early diagnosis of PCa. Further studies are required to correlate the therapeutic strategies for PCa with the combinations of these metabolic markers.

Acknowledgments. This work was supported by research grants from The University of Lahore, Lahore, Pakistan. Authors are thankful to Sharif Medical City Hospital, Lahore for providing support in sample collection.

Conflict of interest. Authors have completed the Unified Conflicts of Interest form at http://ukrbiochemjournal.org/wp-content/uploads/2018/12/ coi_disclosure.pdf and declare no conflict of interest.

Financial Disclosure. No financial disclosure was declared by the authors.

\section{ПРОФІЛЮВАННЯ МЕТАБОЛІЧНИХ БІОМАРКЕРІВ У СИРОВАТЦІ КРОВІ ПАЦІЄНТІВ ІЗ РАКОМ ПРОСТАТИ}

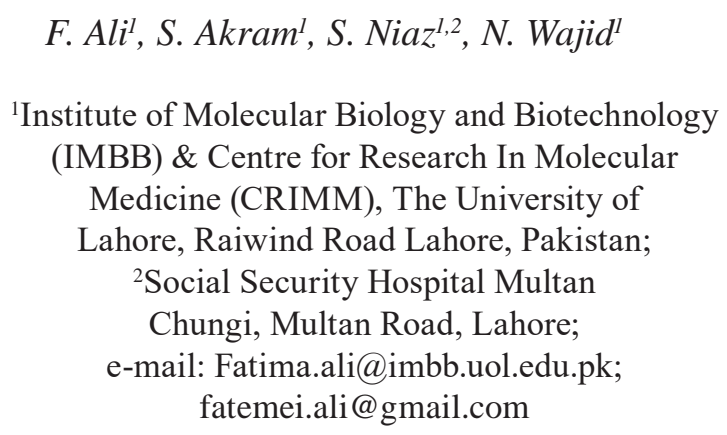

Рак простати (РП) є однією з основних причин смерті чоловіків у всьому світі. $€$ декілька факторів ініціації і розвитку РП. Метою цього дослідження було оцінити різні метаболічні показники в сироватці крові пацієнтів з РП. У дослідженні брали участь чоловіки у віці 50 років і старше 3 нещодавно діагностованим РП (цифрове ректальне дослідження і підвищений рівень простато-специфічного антигену (PSA) в сироватці крові). Рівень глюкози і сироваткових електролітів, активність лактатдегідрогенази, параметри ліпідного обміну і функцію печінки та нирок визначали на автоматизованому аналізаторі з використанням стандартних наборів 
реагентів. Окислювальний стрес оцінювали шляхом вимірювання MDA, CAT, GSH і SOD в сироватці крові. С-реактивний протеїн (CRP), інсуліноподібний фактор росту (IGF-1) і судинний ендотеліальний фактор росту (VEGF) виявляли методом імуноаналізу. Показано, що рівні глюкози і HDL в сироватці крові були нижче, в той час як рівень загального холестеролу, LDL і тригліцеролів були значно вище в групі з РП, ніж у контрольній групі. Пацієнти з РП мали підвищений рівень функціональних маркерів печінки і нирок. Порівняння маркерів окисного стресу в пацієнтів з РП і контрольної групи виявило значну відмінність у показниках. Було виявлено, що рівні CRP, IGF-1 i VEGF у сироватці крові були значно вище в групі з РП порівняно 3 контрольною групою $(P<0,05)$. Низький рівень глюкози і дисліпідемія в пацієнтів з РП вказували на метаболічні зміни. Було продемонстровано важливість деяких параметрів (вільний PSA, дисліпідемія, VEGF, IGF-1, CRP і маркери окислювального стресу) для ранньої діагностики РП.

Кл юч о в і слова: рак простати, окислювальний стрес, інсуліноподібний фактор росту, судинний ендотеліальний фактор росту, C-реактивний протеїн.

\section{References}

1. Taitt HE. Global Trends and Prostate Cancer: A Review of Incidence, Detection, and Mortality as Influenced by Race, Ethnicity, and Geographic Location. Am J Mens Health. 2018; 12(6): 18071823.

2. Jaiswal S, Sarmad R, Arora S, Dasaraju R, Sarmad K. Prostate Cancer for the Internist. $N$ Am J Med Sci. 2015; 7(10): 429-435.

3. Bostwick DG, Burke HB, Djakiew D, Euling S, Ho SM, Landolph J, Morrison H, Sonawane B, Shifflett T, Waters DJ, Timms B. Human prostate cancer risk factors. Cancer. 2004;101(10 Suppl): 2371-2490.

4. Castillejos-Molina RA, Gabilondo-Navarro FB. Prostate cancer. Salud Publica Mex. 2016; 58(2): 279-284.

5. Batty GD, Kivimäki M, Clarke R, Smith GD, Shipley MJ. Modifiable risk factors for prostate cancer mortality in London: forty years of follow-up in the Whitehall study. Cancer Causes Control. 2011; 22(2): 311-318.
6. Khandrika L, Kumar B, Koul S, Maroni P, Koul HK. Oxidative stress in prostate cancer. Cancer Lett. 2009; 282(2): 125-136.

7. Rahman K. Studies on free radicals, antioxidants, and co-factors. Clin Interv Aging. 2007; 2(2): 219-236.

8. Birben E, Sahiner UM, Sackesen C, Erzurum S, Kalayci O. Oxidative stress and antioxidant defense. World Allergy Organ J. 2012; 5(1): 9-19.

9. Yanai Y, Kosaka T, Hongo H, Matsumoto K, Shinojima T, Kikuchi E, Miyajima A, Mizuno R, Mikami S, Jinzaki M, Oya M. Evaluation of prostate-specific antigen density in the diagnosis of prostate cancer combined with magnetic resonance imaging before biopsy in men aged 70 years and older with elevated PSA. Mol Clin Oncol. 2018; 9(6): 656-660.

10. Agalliu I, Adebiyi AO, Lounsbury DW, Popoola O, Jinadu K, Amodu O, Paul S, Adedimeji A, Asuzu C, Asuzu M, Ogunbiyi OJ, Rohan T, Shittu OB. The feasibility of epidemiological research on prostate cancer in African men in Ibadan, Nigeria. BMC Public Health. 2015; 15: 425.

11. Loeb S, Peskoe SB, Joshu CE, Huang WY, Hayes RB, Carter HB Isaacs WB, Platz EA. Do environmental factors modify the genetic risk of prostate cancer? Cancer Epidemiol Biomarkers Prev. 2015; 24(1): 213-220.

12. Hanson ED, Hurley BF. Intervening on the side effects of hormone-dependent cancer treatment: the role of strength training biochemical markers. J Aging Res. 2011; 2011: 903291.

13. Algotar A, Hsu CH, Sherry Chow HH, Dougherty S, Babiker HM, Marrero D, Abraham I, Kumar R, Ligibel J, Courneya KS, Thomson C. Comprehensive Lifestyle Improvement Program for Prostate Cancer (CLIPP): Protocol for a Feasibility and Exploratory Efficacy Study in Men on Androgen Deprivation Therapy. JMIR Res Protoc. 2019; 8(2): e12579.

14. Kim DK, Lee JY, Kim KJ, Hong N, Kim JW, Hah YS, Koo KC, Kim JH, Cho KS. Effect of Androgen-Deprivation Therapy on Bone Mineral Density in Patients with Prostate Cancer: A Systematic Review and Meta-Analysis. J Clin Med. 2019; 8(1): 113.

15. Allott EH, Howard LE, Cooperberg MR, Kane CJ, Aronson WJ, Terris MK, Amling CL, Freedland SJ. Serum lipid profile and risk of prostate cancer recurrence: Results from 
the SEARCH database. Cancer Epidemiol Biomarkers Prev. 2014; 23(11): 2349-2356.

16. Zhang JQ, Geng H, Ma M, Nan XY, Sheng BW. Metabolic syndrome components are associated with increased prostate cancer risk. Med Sci Monit. 2015; 21: 2387-2396.

17. Hsing AW, Sakoda LC, Chua S Jr. Obesity, metabolic syndrome, and prostate cancer. Am J Clin Nutr. 2007; 86(3): s843-s857.

18. Kiwata JL, Dorff TB, Schroeder ET, Gross ME, Dieli-Conwright CM. A review of clinical effects associated with metabolic syndrome and exercise in prostate cancer patients. Prostate Cancer Prostatic Dis. 2016; 19(4): 323-332.

19. Siegel R, Naishadham D, Jemal A. Cancer statistics, 2012. CA Cancer J Clin. 2012; 62(1): 10-29.

20. McGinley KF, Tay KJ, Moul JW. Prostate cancer in men of African origin. Nat Rev Urol. 2016; 13(2): 99-107.

21. Ruseckaite R, Beckmann K, O'Callaghan M, Roder D, Moretti K, Millar J, Evans S. A retrospective analysis of Victorian and South Australian clinical registries for prostate cancer: trends in clinical presentation and management of the disease. BMC Cancer. 2016; 16: 607.

22. Ali F, Naqvi SA, Bismillah M, Wajid N. Comparative analysis of biochemical parameters in diabetic and non-diabetic acute myocardial infarction patients. Indian Heart J. 2016; 68(3): 325-331.

23. He Z, Duan X, Zeng G. Identification of potential biomarkers and pivotal biological pathways for prostate cancer using bioinformatics analysis methods. Peer J. 2019; 7: e7872.

24. Goldner W. Cancer-Related Hypercalcemia. $J$ Oncol Pract. 2016; 12(5): 426-432.

25. Zhang J, Yao YH, Li BG, Yang Q, Zhang PY, Wang HT. Prognostic value of pretreatment serum lactate dehydrogenase level in patients with solid tumors: a systematic review and metaanalysis. Sci Rep. 2015; 5: 9800.

26. Arthur R, Møller H, Garmo H, Holmberg L, Stattin P, Malmstrom H, Lambe M, Hammar N, Walldius G, Robinson D, Jungner I, Van Hemelrijck M. Association between baseline serum glucose, triglycerides and total cholesterol, and prostate cancer risk categories. Cancer Med. 2016; 5(6): 1307-1318.

27. Pelser C, Mondul AM, Hollenbeck AR, Park Y. Dietary fat, fatty acids, and risk of prostate cancer in the NIH-AARP diet and health study. Cancer Epidemiol Biomarkers Prev. 2013; 22(4): 697-707.

28. Zhang GM, Qin XJ, Zhang HL, Xiao WJ, Zhu Y, Gu CY, Dai B, Shi GH, Ye DW. Serum lipid profiles: novel biomarkers predicting advanced prostate cancer in patients receiving radical prostatectomy. Asian J Androl. 2015; 17(2): 239244.

29. Wu X, Daniels G, Lee P, Monaco ME. Lipid metabolism in prostate cancer. Am J Clin Exp Urol. 2014; 2(2): 111-120.

30. Hoeben A, Landuyt B, Highley MS, Wildiers H, Van Oosterom AT, De Bruijn EA. Vascular endothelial growth factor and angiogenesis. Pharmacol Rev. 2004; 56(4): 549-580.

31. Bach LA. Endothelial cells and the IGF system. $J$ Mol Endocrinol. 2015; 54(1): R1-R13.

32. Roberts E, Cossigny DAF, Quan GMY. The role of vascular endothelial growth factor in metastatic prostate cancer to the skeleton. Prostate Cancer. 2013; 2013: 418340.

33. Wu JD, Haugk K, Woodke L, Nelson P, Coleman I, Plymate SR. Interaction of IGF signaling and the androgen receptor in prostate cancer progression. J Cell Biochem. 2006; 99(2): 392-401.

34. Lima GA, Correa LL, Gabrich R, Miranda LC, Gadelha MR. IGF-I, insulin and prostate cancer. Arq Bras Endocrinol Metabol. 2009; 53(8): 969975.

35. Mattsson JM, Ravela S, Hekim C, Jonsson M, Malm J, Närvänen A, Stenman UH, Koistinen H. Proteolytic activity of prostate-specific antigen (PSA) towards protein substrates and effect of peptides stimulating PSA activity. PLoS One. 2014; 9(9): e107819.

36. LeBeau AM, Kostova M, Craik CS, Denmeade SR. Prostate-specific antigen: an overlooked candidate for the targeted treatment and selective imaging of prostate cancer. Biol Chem. 2010; 391(4): 333-343.

37. Nauck MA, Reinecke M, Perren A, Frystyk J, Berishvili G, Zwimpfer C, Figge AM, Flyvbjerg A, Lankisch PG, Blum WF, Kloppel G, Schmiegel W, Zapf J. Hypoglycemia due to paraneoplastic secretion of insulin-like growth factor-I in a patient with metastasizing large-cell carcinoma of the lung. J Clin Endocrinol Metab. 2007; 92(5): 1600-1605. 
38. Meagher EA, FitzGerald GA. Indices of lipid peroxidation in vivo: strengths and limitations. Free Radic Biol Med. 2000; 28(12): 1745-1750.

39. Lobo V, Patil A, Phatak A, Chandra N. Free radicals, antioxidants and functional foods: Impact on human health. Pharmacogn Rev. 2010; 4(8): 118-126.
40. Liu ZQ, Chu L, Fang JM, Zhang X, Zhao HX, Chen YJ, Xu Q. Prognostic role of C-reactive protein in prostate cancer: a systematic review and meta-analysis. Asian J Androl. 2014; 16(3): 467-471. 